\title{
Prevalensi penderita LUTS yang disebabkan BPH di puskesmas Kota Manado tahun 2015
}

\author{
${ }^{1}$ Belva M. Palit \\ ${ }^{2}$ Alwin Monoarfa \\ ${ }^{2}$ P. A. V Wowiling \\ ${ }^{1}$ Kandidat Skripsi Fakultas Kedokteran Universitas Sam Ratulangi Manado \\ ${ }^{2}$ Bagian Ilmu Bedah RSUP Prof. Dr. R. D. Kandou Manado \\ Email: belvapalit12003@gmail.com
}

\begin{abstract}
Lower urinary tract symptoms (LUTS) often occur in elderly population. One of the causes of LUTS in aged males is benign prostatic hyperplasia (BPH). Males with severe LUTS will suffer from decreased libido, difficulty in maintaining an erection, and decreased level of sexual satisfaction. The severity of LUTS was scored by using the International Prostatic Symptom Score (IPSS) is recommended by the World Health Organization (WHO). This study was aimed to determine the prevalence of LUTS in several primary health centers (PHC) in Manado in 2015. This was a descriptive prospective study using data of several health centers in Manado in 2015. The results showed the prevalences of LUTS at several PHC were as follows: Wonasa 6 cases (19\%), Tuminting 9 cases (28\%), Paniki 4 cases (13\%), Tikala 6 cases $(19 \%)$, and Bahu 7 cases (22\%). LUTS were most common at the age of 60-69 years.
\end{abstract}

Keywords: LUTS, BPH, IPSS score

\begin{abstract}
Abstrak: Lower Urinary Tract Symptom (LUTS) sering terjadi pada populasi usia lanjut. Salah satu penyebab yang paling sering ialah benign prostatic hyperplasia (BPH). Lakilakidengan LUTS yang berat akan mengalami penurunan libido, kesulitan mempertahankan ereksi, dan penurunan tingkat kepuasan seksual. Untuk menilai tingkat keparahan dari LUTS digunakan sistem skoring International Prostatic Symptom Score (IPSS). Penelitian ini bertujuan untuk mengetahui prevalensi penderita LUTS di beberapa puskesmas Kota Manado tahun 2015. Jenis penelitian ialah deskriptif prospektif dengan mengambil data di beberapa puskesmas Kota Manado tahun 2015. Hasil penelitian menunjukan prevalensi penderita LUTS di Puskesmas Wonasa 6 kasus (19\%), Puskesmas Tuminting 9 kasus (28\%), Puskesmas Paniki 4 kasus (13\%), Puskesmas Tikala 6 kasus (19\%), dan Puskesmas Bahu 7 kasus (22\%). Penderita LUTS tersering muncul pada usia 60-69 tahun.
\end{abstract}

Kata kunci: LUTS, BPH, skor IPSS

Lower urinary tract symptoms (LUTS) merupakan gejala saluran kemih bagian bawah yang biasanya terjadi pada populasi usia lanjut. ${ }^{1}$ Telah dilaporkan bahwa di Semarang hasil penelitian terhadap 52 laki laki tanpa keluhan usia di atas 40 tahun didapati $88 \%$ ialah IPSS derajat ringan dan $12 \%$ derajat sedang. ${ }^{2}$ Di Korea dilaporkan dari 514 laki laki yang diteliti $16,7 \%$ ialah
BPH dengan IPSS derajat sedang dan 4,5 $\%$ ialah BPH dengan IPSS derajat berat. ${ }^{3} \mathrm{Di}$ Belanda dari 502 laki laki penderita BPH didapatkan $24 \%$ dengan IPSS derajat sedang dan $6 \%$ IPSS derajat berat. ${ }^{4}$ Usia merupakan faktor risiko terbesar untuk persentasi LUTS, dan salah satu penyebab yang paling sering menyebabkan LUTS pada laki-laki lanjut usia ialah Benign 
Prostatic Hyperplasia (BPH). BPH adalah pembesaran jinak dari kelenjar prostat yang terdapat pada laki-laki dikarakteristikan dengan meningkatnya sel-sel stroma dan epitelia pada bangian periuretra prostat. $^{5}$ BPH merupakan istilah histopatologik yang digunakan untuk menggambarkan adanya perbesaran prostat. ${ }^{6}$

Di Indonesia BPH merupakan penyakit tersering kedua setelah batu saluran kemih. Diperkirakan sekitar 5 juta laki-laki diatas 60 tahun menderita LUTS oleh karena BPH. Di RSUP Dr. Cipto Mangunkusumo ditemukan 423 kasus BPH pada tahun 1994-1997. Di RS Sumber Waras ditemukan sebanyak 617 kasus pada tahun yang sama. Di RSUP Prof. Dr. Kandou ditemukan penderita LUTS disebabkan oleh BPH sebanyak 53 kasus selama periode 2009-2013. ${ }^{6}$ Keluhan yang disampaikan oleh pasien BPH seringkali berupa LUTS yang terdiri atas gejala obstruksi (voiding symptom) maupun iritasi (storage symptom) yang meliputi: frekuensi miksi meningkat, urgensi nokturia pancaran miksi lemah dan sering terputus-putus (intermitensi), dan merasa tidak puas sehabis miksi. ${ }^{7,8}$ Untuk menilai tingkat keparahan dari keluhan pada saluran kemih bagian bawah, beberapa ahli urologi membuat sistem skoring yang secara subjektif dapat diisi dan dihitung sendiri oleh pasien. Sistem skoring yang dianjurkan oleh World Health Organization (WHO) ialah skor internasional gejala prostat yaitu International Prostatic Symptom Score (IPSS). ${ }^{9}$ Sistem skoring IPSS terdiri atas tujuh pertanyaan yang berhubungan dengan keluhan miksi (LUTS) dan satu pertanyaan yang berhubungan dengan kualitas hidup pasien.Setiap pertanyaan yang berhubungan dengan keluhan miksi diberi nilai 0 sampai 5, sedangkan keluhan yang menyangkut kualitas hidup pasien diberi nilai 1 hingga 7. Dari skor IPPS itu dapat dikelompokkan gejala LUTS dalam 3 derajat, yaitu ringan: skor 0-7, sedang: skor 8-19 dan berat: skor $20-35 .^{10}$

\section{METODE PENELITIAN}

Jenis penelitian ialah deskriptif dengan desain potong lintang. Kuesioner diberikan kepada pasien dengan gejala LUTS yang disebabkan BPH yang datang di beberapa puskesmas di Kota Manado pada bulan November sampai Desember 2015 yaitu Puskesmas Tuminting, Puskesmas Wonasa, Puskesmas Paniki, Puskesmas Tikala, dan Puskesmas Bahu.

\section{HASIL PENELITIAN}

Penelitian ini dilakukan pada bulan November sampai Desember 2015 di beberapa Puskesmas Kota Manado yaitu Puskesmas Tuminting, Puskesmas Wonasa, Puskesmas Paniki, Puskesmas Tikala, dan Puskesmas Bahu dan diperoleh 32 kasus pasien LUTS. Prevalensi jumlah penderita LUTS yang disebabkan BPH terbanyak di Puskesmas Tuminting 9 pasien (28\%), diikuti oleh Puskesmas Bahu 7 pasien (22\%), Puskesmas Paniki 4 pasien (13\%), dan Puskesmas Wonasa 6 pasien (19\%).

Tabel. 1 Distribusi pasien gejala LUTS yang disebabkan BPH di beberapa puskesmas

\begin{tabular}{ccc}
\hline Puskesmas & Jumlah & Persentase \\
\hline Wonasa & 6 & 19 \\
Tuminting & 9 & 28 \\
Paniki & 4 & 13 \\
Tikala & 6 & 19 \\
Bahu & 7 & 22 \\
Total & 32 & 100 \\
\hline
\end{tabular}

Prevalensi pasien LUTS berdasarkan usia terbanyak ialah 10 pasien $(31,3 \%)$ pada kelompok usia 60-69 tahun, kemudian 8 pasien $(25 \%)$ di kelompok usia $70-79$ tahun, 6 pasien $(18,8 \%)$ di kelompok usia 80-89 tahun, 4 pasien (12,5\%) di kelompok usia 50-59 tahun, 3 pasien $(9,3 \%)$ di kelompok usia 40-49 tahun, dan 1 pasien $(3,1 \%)$ di usia $\geq 90$ tahun.

Mengenai prevalensi skor IPSS hasil yang didapatkan ialah derajat IPSS berat yaitu 14 pasien $(43,75 \%)$, derajat sedang 14 pasien $(43,75 \%)$, dan derajat ringan 4 pasien (12,5\%), dan Puskesmas Tikala 6 pasien $(19 \%)$. 
Tabel 2. Distribusi pasien gejala LUTS berdasarkan usia

\begin{tabular}{ccc}
\hline Usia & Jumlah pasien & \% \\
\hline $40-49$ & 3 & 9,3 \\
$50-59$ & 4 & 12,5 \\
$60-69$ & 10 & 31,3 \\
$70-79$ & 8 & 25 \\
$80-89$ & 6 & 18,8 \\
$\geq 90$ & 1 & 3,1 \\
Total & 32 & 100 \\
\hline
\end{tabular}

Tabel 3. Distribusi pasien LUTS berdasarkan skor IPSS

\begin{tabular}{ccc}
\hline Skor IPSS & $\begin{array}{c}\text { Jumlah } \\
\text { pasien }\end{array}$ & $\begin{array}{c}\text { Persentase } \\
(\mathbf{\%})\end{array}$ \\
\hline Gejala ringan & 4 & 12,5 \\
Gejala sedang & 14 & 43,75 \\
Gejala berat & 14 & 43,75 \\
Total & 32 & 100 \\
\hline
\end{tabular}

\section{BAHASAN}

Hasil penelitian menunjukkan terdapat 32 pasien yang bersedia menjadi responden selama bulan November sampai Desember 2015. Tabel 1 memperlihatkan dari 32 pasien ini didapatkan penderita terbanyak di Puskesmas Tuminting sebanyak 9 orang (28\%) dan yang paling sedikit diPuskesmas Paniki sebanyak 4 orang (13\%). Hasil ini sedikit berbeda dari penelitian Sampekalo et al. ${ }^{6}$ di RSUP Prof. Dr. R. D. Kandou ditemukan penderita LUTS oleh $\mathrm{BPH}$ sebanyak 53 kasus.

Pada Tabel 2 distribusi usia pasien gejala LUTS yang disebabkan BPH didapatkan bahwa golongan usia terbanyak berada pada kisaran antara usia 60-69 tahun, yakni sebanyak 10 pasien $(31,3 \%)$ dan yang terendah pada usia $>91$ tahun yakni 1 pasien $(3,1 \%)$.

Pasien diberikan kuesioner IPSS yaitu untuk menilai tingkat keparahan dari keluhan pada saluran kemih bagian bawah, sistem skoring yang secara subjektif dapat diisi dan dihitung sendiri oleh pasien sistem skoring yang diambil dari American Urological Association (AUA) yang direkomendasikan oleh WHO, kuesioner IPSS terdiri atas tujuh pertanyaan yang berhubungan dengan keluhan miksi
(LUTS) dan satu pertanyaan yang berhubungan dengan kualitas hidup pasien. Dari skor IPSS itu dapat dikelompokan gejala LUTS dalam 3 derajat, yaitu ringan, sedang dan beat. Pada Tabel 3 berdasarkan gejala yang dirasakan tiap responden bervariasi dan didapatkan bahwa dari 32penderita laki-laki usia diatas 40 tahun 14 diantaranya dengan derajat IPSS berat $(43,75 \%)$ dengan skor IPSS berkisaran 2035, diikuti 14 pasien dengan derajat IPSS yang sedang $(43,75 \%)$ dengan skor IPSS berkisaran antara 8-19 dan kedua derajat ini sama banyak.

\section{SIMPULAN}

Dari hasil penelitian di beberapa puskesmas di Kota Manado dapat disimpulkan bahwa jumlah penderita LUTS yang disebabkan BPH terbanyak di Puskesmas Tuminting. Persentase tertinggi pada kelompok usia 60-69 tahun dan yang paling sedikit ialah usia $>90$ tahun. Berdasarkan skor IPSS didapatkan yang tersering ialah IPSS derajat sedang.

\section{SARAN}

Bagi laki-laki yang berusia 40 tahun jika terdapat keluhan (LUTS) disarankan untuk penilaian IPSS secara teliti sehingga tindakan yang diberikan lebih sesuai.

\section{DAFTAR PUSTAKA}

1. Sylvia AP, Lorraine MW. Patofisiologi Konsep Klinis Proses-proses Penyakit (6th ed). Jakarta: EGC, 2012; p. 1320.

2. Nugroho A. Pengaruh faktor usia, status gizi dan pendidikan terhadap internationl prostate symptom score (IPSS) pada penderita prostat hiperplasia [Skripsi]. Semarang: Universitas Diponegoro; 2006.

3. Lee E, Park C, Lee $\mathrm{H}$. A high risk group of protatism: A population based epidemiological study in Korea. $\mathrm{Br} \mathbf{J}$ Urol. 2004;79:736-41

4. Bosch JL, Hop WC, Kirkels WJ, Schroder FH. The international prostate symptom score in community based sample of men beetween 55 and 74 years of age: prevalence and corelation of symptoms. $\mathrm{Br} \quad \mathrm{J} \quad$ Urol. 
2008;75(5):622-30.

5. Fitri M. Penerapan preoperative teaching pada klien dengan masalah bedah benign prostatic hyperplasia- transuretral resection of the prostate (BPH-TURP) [Skripsi]. Depok: Universitas Indonesia; 2013.

6. Sampekalo G, Monoarfa RA, Salem. Angka kejadian LUTS yang disebabkan BPH di RSUP Prof. Dr. R. D. Kandou Manado periode 2009-2013. eCL. 2015:3;568-72.

7. Barkin J. Benign prostatic hyperplasia and lower urinary tract symptoms: evidence and approaches for best case management. Can J Urol. 2011. 7

8. Emberton M, Cornel EB, Bassi PF, Fourcade RO, Gomes JMF, Castro

R. Benign prostatic hyperplasia as a progressive disease: a guide to the risk factors and options for medical management. Int $\mathbf{J}$ Clint Pract. 2008;62(7):1076-86.

9. Basuki BP. Dasar-dasar Urologi (3rd ed). Malang: SS, 2012; p.16 9.

10. Pierce AG, Neil RB. At a Glance Ilmu Bedah (3rd ed), alih bahasa Umami V. Jakarta: Erlangga, 2007; p. 31-3. 